\title{
A Mountain Too Far? The Saga of Social Security Personal Accounts
}

\author{
Sheila Bair \\ Isenberg School of Management, University of Massachusetts, 121 Presidents Drive, no 320, Amherst, \\ MA 01003, U.S.A. \\ E-mail: sbair@som.umass.edu
}

As a pay-as-you-go system, Social Security faces severe long-term financing challenges stemming from a rapidly growing retirement population, continued low fertility rates, and increased longevity. Unfortunately, the political debate in the U.S. over how to "fix" Social Security has become polarized. Republicans, led by the Bush Administration, have argued for partial advance funding of Social Security through the establishment of voluntary personal accounts and a scaling back of the index formula used to establish initial benefits for higher income workers. Democrats have vigorously attacked personal account proposals as attempts to "privatize" Social Security. After reviewing historical consideration of personal accounts and the current debate over them, the paper concludes that personal accounts funded through the diversion of payroll taxes supporting traditional benefits are not politically viable and are impeding bipartisan discussions over ways to address Social Security's solvency. The paper endorses a strategy proposed by Senator Robert Bennett (R-Utah) to engage in negotiations with Democrats over solvency measures separately from consideration of personal accounts.

The Geneva Papers (2005) 30, 581-592. doi:10.1057/palgrave.gpp.2510055

Keywords: social security; social security reform

\section{Introduction}

"The President had two mountains to climb on Social Security," opines Senator Robert Bennett (R-Utah) as he and his staff chat with me in his office in the U.S. Capitol. "The first peak was convincing the American people that there is a solvency problem, and he has successfully scaled that mountain. The second peak was making the case for structural reform and personal accounts. He has not yet scaled that mountain, but he is in a better position to conquer it now that he can see the view from the top of the first peak."

The metaphor aptly describes the current state of the debate in the U.S. over Social Security, a crown jewel of the New Deal era that provides nearly 48 million Americans with retirement, survivors, or disability benefits. The President has made it politically viable to openly discuss problems with our Social Security system, which was traditionally viewed as the untouchable "third rail" of U.S. politics. And he has made great strides in convincing the American public that solvency problems do exist problems, which will only get worse the longer the Congress waits to address them. But he has not yet garnered consensus support for reforming the system to give Social Security participants the option of diverting some portion of their payroll contributions into personal accounts, which they could invest in the private capital 
markets. Indeed, the most recent polls show public support for personal accounts declining, notwithstanding the Administration's vigorous advocacy efforts.

The President has encouraged Senator Bennett's effort to engage Congressional Democrats on the first peak of the debate - solvency - while maintaining his strong support for personal accounts. Senator Bennett, a successful businessman before his election to the Senate 13 years ago, is a highly influential member of the Senate GOP leadership. He conducted extensive research and hearings on Social Security's problems last year when he chaired the Joint Economic Committee. As of this writing, he was preparing a bill which would address 90 per cent of Social Security's anticipated funding shortfalls by revising the index formula used to calculate benefits for higher income workers and gradually increasing the retirement age. A second bill, which he will introduce at a later date, would propose Social Security personal accounts, as well as other reforms affecting the private pension system. (Both bills are described in more detail later in this paper.) Senator Bennett's strategy is to draw the Democrats out of their "attack position" on personal accounts by offering to engage in separate negotiations on solvency. As the respected political journalist David Broder observed in a recent Washington Post column, "The insolvency problem is real and it needs to be fixed. ... If they are responsible, Democrats will take Bennett at his word ... to balk at such an offer would be a sign that they are putting politics above the national interest."

And the national interest requires action - the sooner, the better. According to the most recent annual estimate prepared by the Trustees of the Social Security and Medicare Trust Funds ${ }^{2}$, Social Security benefits already represent 4.3 per cent of Gross Domestic Product (GDP) and will grow to 6.4 per cent of GDP by 2079. Social Security benefits are supported by a 12.4 per cent payroll tax. Tax revenues not needed in the current year to pay benefits and administrative costs are placed in the Social Security Trust Funds ${ }^{3}$ and invested in special issue debt obligations of the U.S. Government. Surpluses accumulating in the Trust Funds will peak in 2017. At that point, the System will need to utilize interest payments on the debt obligations to pay benefits, and by 2027, it will need to begin redeeming those securities. By 2041, the

${ }^{1}$ Broder (2005).

${ }^{2}$ There are six trustees of the Social Security and Medicare Trust funds. They include the Secretaries of the Departments of Treasury, Labour, and Health and Human Services; the Commissioner of Social Security, and two public members appointed by the President. Each year the trustees report on the current status and projected condition of the Social Security and Medicare Trust Funds over the next 75 years.

3 The trust funds were created in the U.S. Treasury Department to account for all programme income and disbursements. The trust funds represent the accumulated value, including interest, of all prior programme surpluses. There are four separate trust funds. For Social Security, retirement and survivours benefits are paid by the Old-Age and Survivors Insurance (OASI) Trust Fund and disability benefits are paid from the Disability Insurance (DI) Trust Fund. The combined funds are commonly referred to as OASDI. For Medicare, there are also two trust funds: the Hospital Insurance (HI) Fund that pays for inpatient hospital and related care and the Supplementary Medical Insurance (SMI) Trust Fund that pays for physician, outpatient, and a prescription drug benefit which begins in 2006. The discussion in this paper is confined to issues associated with OASDI. As many commentators have pointed out, the Medicare Trust Funds confront even more severe solvency issues. Current projections indicate that the HI Fund will be exhausted by 2020 . 
surpluses will be exhausted, and Social Security payroll taxes will be sufficient to cover only 74 per cent of benefits. Thus if the Congress does nothing, funding shortfalls will necessitate across-the-board reductions of 26 per cent. By 2078, payroll taxes will be sufficient to cover only 68 per cent of benefits, necessitating reductions of 32 per cent. In contrast, if Congress acts now, the System could be brought into actuarial balance through a 15 per cent payroll tax increase, a 13 per cent benefit cut, or some combination of both. The longer Congress waits, the harder the choices will be to restore long-term solvency to the System.

By taking personal accounts off the table - for now - Republicans such as Bennett are hoping to jump-start negotiations and motivate Democrats to either join them, or come up with their own plan to provide for long-term solvency and avert the need for major across-the-board benefit reductions in the future. Across-the-board cuts would fall disproportionately on low-income families, given their higher reliance on Social Security for retirement income support. Among poor households of retirement age, Social Security is virtually the only source of retirement income.

Are personal accounts in their death throes? Or can solvency issues be addressed separately without prejudicing the ability of personal account advocates to fight another day? To analyze that question, some background on the history of Social Security and the evolution of reform proposals is necessary.

\section{Contributory annuities: FDR's original vision}

The Social Security System's solvency woes are, of course, symptomatic of all systems whereby the contributions of current workers fund benefits of retirees and other beneficiaries. Such pay-as-you-go systems work well when the work force is growing at a more rapid rate than that of the beneficiary population. However, a major demographic shift is taking place in the U.S. and throughout the world. The ageing of the baby boom population, together with continuing low fertility rates and increasing life expectancies, mean that relatively fewer workers will be available to support a growing elderly population. Indeed, in the 1950s, there were 16 workers for every Social Security beneficiary. Today, there are a little over three workers to support beneficiaries. In a generation, that number will fall to just over two.

Ironically, when President Franklin Delano Roosevelt first proposed Social Security legislation, he envisioned it as a system of retirement annuities, funded by workers' own contributions. In his January 1935 message to Congress, he called for "noncontributory old-age pensions for those who are now too old to build up their own insurance" as well as "compulsory contributory annuities which in time will establish a self-supporting system for those now young and for future generations." Accordingly, the two major provisions of the Social Security Act adopted by the Congress in 1935 were Title I, providing grants for state welfare programmes for the aged and Title II - the precursor of today's system - providing for benefits based on a worker's own payroll tax contributions. Interestingly, FDR's 1935 message also envisioned "voluntary contributory annuities by which individual initiative can increase the annual amounts received in old age." Seventy years later, that vision is still being debated. 
This new social insurance programme was intended to provide a financially stable contributory system in which the workers themselves contributed to their own future retirement benefit by making regular payments into a joint fund. However, given the demands of the post-Depression economy and the acute recession of 1938, Congress made fundamental changes in the Social Security programme in 1939. Specifically, Congress added two new categories of benefits: dependents' benefits for retired workers and survivors' benefits payable to families in the event of the premature death of a covered worker. Thus, Social Security was transformed from a retirement programme for workers to an economic security programme for workers and their families. And to meet expanded benefit obligations, instead of being a fully funded system, it became a system for the transfer of income from younger to older generations.

In the 1970s, further benefit increases and expansions, including automatic cost of living increases, combined with a sour economy, provoked Social Security's first major short-term funding crisis. In 1977, Congress made incremental changes in the payroll tax and benefit levels which proved to be woefully inadequate. In 1983, the System confronted an immediate funding shortfall of \$150-200 billion, as well as long-term insolvency stemming from the projected retirement of the baby boom population. President Ronald Reagan appointed a bipartisan commission chaired by Alan Greenspan which, in a remarkable display of statesmanship, agreed to a consensus package of reforms, which averted the immediate crisis and permitted the system to build a surplus - a surplus which will continue to grow until 2017. Based on the Greenspan Commission's recommendations, the Congress enacted numerous changes, including the taxation of Social Security benefits; future, graduated increases in the retirement age; and coverage of federal employees in the system.

The Greenspan Commission bought time, but it did not solve the Systems' longterm solvency challenges. The Clinton Administration commissioned three national panels to review reform options: the Bipartisan Commission on Entitlement and Tax Reform (1993-1995); the Advisory Council on social Security (1994-1996); and the National Commission on Retirement Policy (1997-1998). All three panels issued reports, which included personal accounts as one option for reform. Press reports suggest that Treasury officials in the Clinton Administration seriously considered personal accounts, but they were never formally proposed by that Administration.

\section{The Bush administration's efforts at structural reform}

During his first Presidential campaign, then Governor Bush called for personal accounts as part of his larger vision for an "ownership society":

Ownership in our society should not be an exclusive club. Independence should not be a gated community. Everyone should be part owner in the American dream.

During the first year of his Administration, President Bush appointed a bipartisan commission to examine structural reforms, including personal accounts, to sustain 
Social Security. The commission - chaired by the late Democratic Senator Daniel Patrick Moynihan and co-chaired by corporate executive Richard Parsons - issued its final report in December 2001, and concluded that "the time to include personal accounts has arrived." 4 The report included three reform models, all of which provided for alternative means to allow workers to voluntarily "carve out" a small amount of their payroll taxes for investment in the bond and equity markets. Traditional benefits would be offset by workers' personal account contributions. In advancing the case for personal accounts, the Commission framed the principal arguments in their favour:

- Personal accounts would provide for partial advance funding of retirement income, thus strengthening the financial integrity of the system and making it more sustainable;

- Retirement security would be increased because personal accounts facilitate wealth creation for individual Social Security participants. Drawing on academic research, the Moynihan Commission found that asset holding contributes to positive psychological and behavioral changes, including a greater feeling of economic security and willingness to save;

- Financial security would be enhanced through asset ownership, unlike a claim to benefits which is continually subject to political negotiation. As with any federal entitlement programme, Social Security benefits are subject to rule changes. Personal accounts would be more secure from Congressional interference;

- Personal accounts would provide inheritable assets. The Moynihan Commission found that the ability to pass on assets at death would be of particular benefit to African-American male workers and other demographic groups, who on average have lower incomes and expected life spans;

- Personal accounts would permit individuals to obtain a higher return on payroll contributions. Most estimates place the rate of return on payroll tax contributions at 2 per cent under the traditional system. The Moynihan Commission found that workers could expect significantly higher returns on suitable capital market investments with a resulting increase in total benefits;

- Personal accounts would likely lead to an increase in national savings and encourage labour force participation. Observing that historically, Social Security surpluses had been used to support government deficit spending, the Commission found that diverting a portion of payroll taxes into the capital markets would increase national savings. The Commission also found that personal accounts would provide incentives for labour force participation because the contributions were less likely to be viewed as a "tax".

Notwithstanding the strong recommendations and supporting analysis provided by the Commission, the Bush Administration, recognizing the inherent susceptibility of personal accounts to politicization, decided to foster further public debate on the issue. At the beginning of the President's second term, however, Social Security reform and personal accounts became a major Administration domestic priority. The President

\footnotetext{
${ }^{4}$ Moynihan and Parsons (2001).
} 
and his entire economic team implemented an intensive public education effort regarding the Social Security System's long-term solvency problems and the importance of personal accounts to achieve lasting structural reform. Just as vigorously, opponents, including Congressional Democrats and powerful grassroots organizations such as the American Association of Retired Persons (AARP), decried personal accounts as "privatizing" Social Security. The principal arguments they have advanced against personal accounts are:

- Personal accounts, by diverting a portion of current payroll taxes, worsen solvency and increase the need for benefit reductions or tax increases. The revenue flowing into personal accounts would precede by many decades offsetting reductions in traditional benefits. For instance, if workers were allowed to contribute 2 per cent of payroll to personal accounts, with an offsetting reduction in traditional benefits, there would be no impact on Social Security in present value. However, the cash flow would be negative over a period of more than 45 years - the length of time it would take for benefit offsets to exceed diverted revenue. ${ }^{5}$

- Personal accounts would expose Social Security participants to market risk. This risk may be most acute among low-income workers who may not have the same investment skills as upper income earners. Given the dramatic shift in private pensions to defined contribution plans such as $401(\mathrm{k}) \mathrm{s}$ and IRAs, which require workers to assume the market risk of their investments, it makes little sense to add further risk under Social Security through personal accounts. Workers need at least one stable, reliable source of income that keeps pace with inflation and lasts as long as they live.

- Personal accounts are unlikely to offer the same protections against inflation, outliving one's assets, and for dependents, against a workers' premature death, as do Social Security benefits. Thus, while "inheritability" may advantage workers with average shorter life spans, personal accounts would not provide the same level of income protection to the dependents and survivors of those workers.

- Personal accounts will create pressure from Social Security participants for early withdrawal of benefits, which could undermine retirement security.

- Without a budget surplus or additional taxes, personal accounts do not contribute to national savings and by decreasing revenues which support current benefits, put the future of Social Security more at risk.

Despite the Administration's intensive effort to garner public support for personal accounts, polls have consistently shown the opponents' view prevailing among a majority of the public. According to the most recent Gallup poll, conducted on June 30,2005 , only 44 per cent of survey respondents supported personal accounts, with 53 per cent opposed. Party affiliation accounted for the biggest distinction in support, with two-thirds of Republicans favouring the idea, and nearly three-fourths of Democrats opposing. However, the difference in age groups was almost as stark, with 57 per cent of respondent's aged 18-29 years supporting personal accounts, and 51 per cent of those aged 30-49 years supporting them. In contrast, 63 per cent of those aged

\footnotetext{
${ }^{5}$ Orszag $(2004 a, b)$.
} 
50-64 years opposed personal accounts, and 57 per cent of those over 65 opposed them. The relatively strong support for personal accounts among younger generations is consistent with my informal polling of my own students, most of whom are staunch Democrats. They predominantly hold the view that there will be nothing left of Social Security when they retire, so they prefer personal accounts, which will give them an ownership right to the assets. But there are other rationales. One student, a particularly strong opponent of the Bush administration, told me that he supported personal accounts, because he did not want his Social Security payroll taxes supporting government financing of the war in Iraq...

\section{Enter Senator Bennett}

Against this backdrop, Senator Bennett has come forward with a two-pronged legislative approach. First, as previously mentioned, he wants to tackle Social Security's solvency problems separately from personal accounts. Though Senator Bennett strongly supports personal accounts, he does not want the lack of consensus support for them to stand in the way of addressing Social Security's long-term insolvency. His bill to address Social Security's long-term funding shortfalls includes three components.

\section{Progressive indexing}

When the Social Security Administration sets a worker's initial ${ }^{6}$ retirement benefits, it adjusts his/her prior earnings to reflect growth in wages. On average, wages outpace inflation by about 1 per cent per year, so that wage indexing initial benefits results in a significantly higher benefit than would adjustments based on price increases. The difference can be dramatic. An individual making $\$ 20,000$ in 1970 would make $\$ 97,454$ today, if her salary was indexed for inflation. In other words, $\$ 97,454$ would give the worker the same purchasing power that she had in 1970 making $\$ 20,000$. However, if her wages were adjusted to reflect overall wage growth, that same individual would be making $\$ 119,000$ today. Wage indexing accounts for overall increases in the standard of living and guarantees that future initial retirement benefits will grow faster than "real dollar" value over time. In the above example, it assumes the worker was paid 20 per cent more in 1970 than she actually earned. ${ }^{7}$

Replacing wage with price indexation for the purpose of establishing initial benefits is highly controversial. Robert Pozen, a Democrat financial executive and member of the Moynihan Commission, has proposed an approach called "progressive indexing" which is the approach adopted by Senate Bennett and is also supported by the President. Under progressive indexing, individuals in the lowest 30 per cent of all wage earners (below $\$ 25,000$ per year) would continue to have their past wages indexed

\footnotetext{
${ }^{6}$ Once initial benefits are set, Social Security also provides for automatic, annual cost of living adjustments (COLAs), which are indexed to the Consumer Price Index. Many economists feel that the CPI overstates cost of living increases, though this is a separate issue and is not addressed in the Bennett bill.

${ }^{7}$ Joint Economic Committee (2005).
} 
according to wage growth for purposes of determining their initial benefits. Those in the top 30 per cent (above $\$ 113,000$ per year) would have their past wages indexed for changes in prices. Those in the middle would have their past wages indexed based upon a "progressive blend" of wage and price increases. ${ }^{8}$

\section{Longevity indexing and retirement age}

The average life expectancy of Americans turning 65 in 1940 was 78. For Americans turning 60 this year, it is 83 . By 2040, it will be 85 . This demographic trend, in addition to the sheer size of the retiring baby boom population, is a major factor driving Social Security's long-term insolvency. Virtually every public policy expert appearing before Congress has recommended that this issue be addressed, through a reduction of life time benefits, an increase in the age at which beneficiaries are eligible for retirement, or some combination of both. Unfortunately, though raising the retirement age is popular with Social Security experts, it is one of the least popular options among the American population who, polls show, want to retire earlier, not later.

Pursuant to the 1983 amendments, the age at which a worker can retire with full benefits (the Normal Retirement Age or NRA) will gradually increase to 67 in 2022. Senator Bennett's bill will slightly accelerate the increase in the NRA to 67 by the year 2017. Thereafter, initial benefits will be periodically adjusted to account for changes in the expected average life times of future retirees.

\section{Protection of disabled workers}

Senator Bennett would exempt disability beneficiaries from the application of changes to benefit formulas while they are disabled. Once they reach retirement - and their benefits begin to be paid by the Old Age and Survivor Trust Fund - their benefit formulas would be adjusted.

Senator Bennett's proposal deals exclusively with the benefit side of the equation and thus has already been attacked by some Democrats, who presumably prefer tax increases to restore solvency to the system. Whether Senator Bennett can draw them to the negotiating table will depend on their own political calculation as to what will cause the least damage: (1) developing a solvency proposal which will inevitably have to include higher taxes, benefit cuts, or both; or (2) taking no action, which will only make the need for later benefit cuts/tax increases more severe. Complicating Senator Bennett's strategy is continued insistence by House Republicans and some Senate GOP conservatives that solvency and personal accounts be dealt with in the same package. He must convince Senate Democrats that it is in their best interests to negotiate. And he must convince personal account proponents that an agreement on solvency will not prejudice their ability to secure structural reform.

What would Senator Bennett propose regarding personal accounts? His proposal recognizes that Social Security personal accounts are only one component of assuring

\footnotetext{
${ }^{8}$ Pozen (2004).
} 
security for America's burgeoning retirement community. Thus, he addresses needed structural reforms in both Social Security and the private pension system.

\section{Social security “carve in" personal accounts}

In contrast to the "carve out" accounts contemplated in other personal account proposals, Senator Bennett would propose creating voluntary "carve in" accounts. Under this approach, workers could contribute an additional 2 per cent of their wages into a personal account. If they did so, payroll tax contributions equal to 2 per cent of their covered wages would be moved into the personal account as well. Benefits from the traditional system would be offset to reflect the lower level of these workers' tax contributions.

The "carve in" approach - by requiring that workers help fund personal accounts with an additional, voluntary payroll contribution - should help mitigate transition costs associated with "carve out" accounts where the personal accounts are funded entirely through existing payroll taxes. As such, it addresses one of the most powerful arguments advanced against personal accounts - that while over the long term, personal accounts contribute to system solvency, during the transitional phase, personal accounts exacerbate Social Security's financing problems by diverting payroll tax income which would otherwise be available to support traditional benefits.

Senator Bennett would address concerns about workers assuming market risk with personal accounts by limiting investment choices to the relatively tame options now provided to federal employees in their Thrift Savings Plan (TSP). The TSP is essentially a 401(k) plan for federal government workers. Established in 1986, it provides five straightforward investment options: a government securities fund; a fixed income (corporate) investment fund; a common stock index fund; a small cap index fund, and an international stock index fund. The funds are well managed and costs are low. It is extremely popular with federal workers. Over 85 per cent of federal employees participate in the programme.

\section{Private pension reforms}

Senator Bennett will also include in his legislation reforms to increase participation and savings in private pension vehicles. His private pension reforms build on research conducted by Professor Richard H. Thaler at the University of Chicago, which seeks to incorporate modern psychology theory into economic analysis. Thaler's research finds that there is enormous inertia regarding employees' participation in employersponsored retirement vehicles. His research shows that the simple step of making participation in such plans automatic improves participation rates dramatically. For instance, in testimony before Congress, Thaler cited one company, which had a 49 per cent participation rate among new workers in its $401(\mathrm{k})$ plan. The company used an "opt in" approach for participation - that is, employees had to affirmatively decide to participate and fill out a form so specifying. The company then shifted to automatic enrollment. That is, it told its new employees that they would be automatically enrolled in the 401(k) plan unless they filled out a form "opting out" of participation. 
As a result of this one change, the participation rate among new workers jumped to 86 per cent. ${ }^{9}$

Thaler has also found that it is easier to convince workers to save in the future, than it is to convince them to increase the current portion of income they devote to savings. As a consequence, he and his collaborator, Shlomo Benartzi of the University of California at Los Angeles (UCLA), have developed the Save More Tomorrow Plan, also known as the SMarT plan. Under SMarT, workers are contacted by their employer a few months before their next scheduled pay increase and asked if they want to increase their savings when they get their raise. Like automatic enrollment, SMarT has been highly successful. Thaler cites one example where over 80 per cent of employees contacted signed up for SMarT and in the course of 2 years, quadrupled their savings rates.

Senator Bennett's proposed legislation draws from this research by encouraging employers to provide for automatic enrollment or "opt out" for new employees' participation in $401(\mathrm{k}) \mathrm{s}$ and other tax deferred retirement vehicles, as well as offer "SMarT" type programmes allowing employees to automatically save an increased portion of future raises. As an enticement, the Bennett bill would deem employers offering such programmes as in compliance with various nondiscrimination requirements - complex rules designed to ensure that tax benefits associated with employee retirement plans do not unduly benefit higher paid workers. If Thaler's research is any indication, widespread adoption of automatic enrollment and SMarT plans could result in dramatically improved savings rates among American workers.

\section{Will Senator Bennett succeed?}

The Social Security debate is at a stalemate, polarized over personal accounts. Senator Bennett's strategy offers the best hope of jump starting negotiations on solvency, while preserving GOP's, prerogatives to continue pushing personal accounts. Personal account advocates, led by the best spokesperson possible, President Bush, have worked tirelessly over the past 18 months to educate the public on their benefits. However, what may be good policy may not be workable politics. The same demographic changes responsible for Social Security's financing problems are also partly responsible for a political climate hostile to structural reform.

The rapidly growing numbers of Americans who are retired or close to retirement have highly sophisticated and effective lobbying organizations advocating against personal accounts. Older Americans have the least to gain from personal accounts, and the most to fear, given the concerns about transition costs. Younger workers those with the most to gain from personal accounts and the most to lose from future benefit reductions if Congress does nothing - are a less potent political force and do not have an effectively organized lobbying organization. In addition, older Americans and their advocates are more motivated on the issue because they have a real and

\footnotetext{
${ }^{9}$ Thaler (2004).
} 
tangible need to maintain traditional benefits. In contrast, for younger workers, personal accounts are a mere political abstraction.

All that can be done to advocate personal accounts has been done. Continued advocacy appears to be weakening, not strengthening, public support. Moreover, political polarization over the issue is impeding a meaningful dialogue on the one area where all generations want action - solvency. Perhaps it is time to let personal accounts rest - for a while. Continued insistence that reform efforts address the two issues together will only result in more arguments from opponents over Social Security "privatization" - and more fear among older Americans - as well as ease pressure on private account opponents to come up with a viable alternative plan.

Moreover, private account proponents should be receptive to modified proposals along the lines proposed by Senator Bennett. Many Democrats have acknowledged that private accounts could benefit lower income workers, only one-fifth of whom participate in private retirement vehicles such as $401(\mathrm{k}) \mathrm{s}$ or IRAs. Democrats have suggested that they would support personal accounts if they were "add on" accounts, that is, those funded with contributions over and above the payroll tax. Senator Bennett's carve-in approach is a good compromise between carve-out accounts and "add-ons". Enactment of "carve-in" accounts would transform personal accounts from a political abstraction to a concrete reality, helping to build a stronger constituency for them and perhaps creating a better climate for more extensive reforms down the road.

I recently had occasion to ask my former boss, Senator Robert Dole, who, in 1983, was Chairman of the Senate Finance Committee and co-chairman of the Greenspan Commission, why bipartisan consensus was so attainable in 1983 and so elusive today. His response was simple: "We had to act or the checks were not going to go out." Let us hope that Congress does not wait this time for an impending crisis before it acts. With each passing year, the choices will become more difficult. As a member of the baby boomer generation, an insolvent Social Security system is not the legacy I want to leave my children, nor is it the legacy that I believe others of my generation want to leave as well.

\section{References}

American Association of Retired Persons (2005) 'Policy on social security', www.aarp.org, downloaded from website on July 7, 2005.

Bennett, R. and Legislative Office (2005) 'Summary of senator Bob Bennett's social security legislation', available at www.bennett.senate.gov.

Broder, D. (2005) 'A social security plan to talk about', The Washington Post, June 2, 2005.

Brown, J. (2004a) 'Don't just save social security, improve it', Advance, TIAA-CREF.

Brown, J. (2004b) 'The case for pre-funding social security', Generations, American Society on Aging.

Bush, G.W. (2005) 'Presidential statements on social security', available at www.ssa.gov/history.

Council of Economic Advisors (2002) '2002 Economic Report of the President', Chapter 2, available atwww.gpoaccess.gov.

DeWitt, L. (2003) 'A brief history of social security', available at www.ssa.gov/history.

Joint Economic Committee (2005) 'Understanding progressive indexing', available at www.jec.senate.gov.

McCabe, B. (2005) 'Preserving social security for future generations: Social security is now a young people's issue', Saturday Evening Post, May 1. 
Moynihan, P. and Parsons, R. (2001) 'Strengthening social security and creating personal wealth for all Americans', President's Commission to Strengthen Social Security.

Orszag, P. (2000) 'Voluntary individual accounts for social security: What are the costs?', Center on Budget and Policy Priorities.

Orszag, P. (2004a) 'Strengthening retirement security', Testimony before the Joint Economic Committee, March 10.

Orszag, P. (2004b) 'What's the best way to fix social security?', Advance, TIAA-CREF.

Pozen, R. (2004) 'Testimony before the Joint Economic Committee', March 10.

Roosevelt, F.D. (1935) 'Message to congress on social security', January 17, available at www.ssa.gov/ history.

Saad, L. (2005) 'Little for bush to savor in the latest social security polling', Gallup News Service, June 30 , 2005.

Social Security Administration (2005) 2005 Annual Report of the Board of Trustees of the Federal Old-Age and Survivors Insurance and Disability Insurance Trust Funds.

Thaler, R. (2004) 'Helping Americans save', Testimony before the Joint Economic Committee (March 10, 2004).

Thaler, R. and Benartzi, S. (2004) 'Save more tomorrow: Using behavioral economics to increase employee saving', Journal of Political Economy 12(1): 164-187.

Toner, R. and Rosenbaum, D. (2005) 'In overhaul of social security, age is the elephant in the room', The New York Times, June 12.

Washington Times (2005) 'Bill Clinton's Social Security Options', January 30.

\section{About the Author}

Sheila Bair is the Dean's Professor of Financial Regulatory Policy at the University of Massachusetts Isenberg School of Management. She has previously held positions as the Assistant Secretary for Financial Institutions in the U.S. Department of the Treasury, Senior Vice President of Government Relations for the New York Stock Exchange, Commissioner and Acting Chair of the Commodity Futures Trading Commission, and Research Director and Counsel to Senate Majority Leader Robert Dole. She has a JD and BA from the University of Kansas. She serves on advisory committees to the Federal Deposit Insurance Corporate (FDIC) and the National Association of Securities Dealers (NASD) and on the boards of the Center for Responsible Lending and the Insurance Marketplace Standards Association (IMSA). She has published several articles in the field of financial regulation and has testified before Congress on numerous occasions.

Bair also writes for children, particularly in the areas of money and finance. She has received many awards for articles she has written for Highlights magazine, most recently being recognized by the Association of Educational Publishers. Her first children's book, Rock, Brock and the Savings Shock, will be published by Albert Whitman \& Co. in 2006. 